\title{
Model Bisnis Triple Bottom Line Pasar Komunitas Makanan Sehat dan Pengembangannya dalam Mewujudkan Rantai Pasok Pangan Berkelanjutan
}

\author{
Kristia \\ Program Studi Manajemen, Fakultas Ekonomi, Universitas Sanata Dharma, Indonesia \\ kristia9ie@gmail.com
}

\begin{abstract}
The purpose of this study is to map explicitly about the triple bottom line business model that has been practiced by three healthy food community markets in Yogyakarta, namely Pasar Kamisan, Pasar Moncer, and Pasar Mustokoweni. The research method uses a qualitative method, especially with a multi-sites approach, where data obtained from the process of observation and in-depth interviews with stakeholders. Data analysis uses combination of business model canvas approach and SPOT matrix analysis. The study reveals that the community market needs to innovate performance on the nine blocks of their triple bottom line business model in terms of improving the quality of organizational performance and playing an optimal role in realizing a sustainable food supply chain.
\end{abstract}

Keywords: Business Model, Community Market, Sustainable Food Supply Chain, Triple Bottom Line

\section{PENDAHULUAN}

Dalam

rangka

mencapai keberlanjutan, selain mengandalkan teknologi terkini suatu organisasi dapat melakukan inovasi pada model bisnis yang dimilikinya (Geissdoerfer et al, 2017). Menurut Osterwalder dan Pigneur (2010), kanvas model bisnis tidak hanya dapat dimanfaatkan oleh perusahaan yang berorientasi pada laba, namun organisasi amal, nirlaba, lembaga pemerintah, dan usaha sosial berorientasi laba juga dapat memanfaatkan alat bantu ini untuk mendeskripsikan, menganalisis, dan merancang model bisnisnya. Walaupun tidak berorientasi kepada profit, sebuah organisasi pada dasarnya tetap memiliki model bisnis karena organisasi tersebut memiliki nilai utama yang diperjuangkan dan tetap perlu memiliki arus pendapatan untuk menutupi biaya-biaya yang digunakan untuk mewujudkan nilai keutamaannya. Model bisnis melampaui keuntungan (beyond-profit business model) merupakan model bisnis yang tepat untuk digunakan pada organisasi yang memiliki proposisi nilai yang terkait dengan perwujudan pemecahan masalah sosial dan lingkungan sekitar. Topik inovasi model bisnis terutama untuk mewujudkan keberlanjutan saat ini semakin mendapat perhatian dari pihak pemerintah dan para pemimpin di berbagai bidang industri. Hal ini memberikan peluang bagi peneliti di bidang manajemen untuk berkontribusi pada studi inovasi model bisnis yang berkelanjutan (Osterwalder \& Pigneur, 2010; Breuer et al, 2018).

Sistem pangan berkelanjutan merupakan jaringan kolaboratif yang mengintegrasikan berbagai komponen pada 
rantai pasok makanan untuk meningkatkan kesejahteraan lingkungan, memberdayakan Usaha Mikro, Kecil, dan Menengah (UMKM), meningkatkan ekonomi masyarakat desa, mematahkan monopoli agribisnis dan menciptakan hubungan spiritual antara manusia dan alam. (Halweil, 2004; Smith, 2008; Calgary, 2012). Menurut Bash \& Donnely (2019), sistem pangan berkelanjutan dapat diwujudkan dengan berbagai cara, yaitu dengan mempromosikan penggunaan bahan makanan musiman, lokal, organik, dan sumber daya yang bertanggung jawab; skema yang mempromosikan sumber protein nabati; dan skema yang melibatkan orang maupun organisasi untuk beralih ke diet sehat berkelanjutan. Rantai pasokan pangan yang menggunakan bahan lokal digolongkan sebagai praktik pangan keberlanjutan, karena umumnya hal tersebut mendukung pertanian dengan metode organik, mengurangi emisi yang dihasilkan oleh transportasi jarak jauh dan foodmiles yang tinggi (Jones, 2001; Pretty et al, 2005 Sustain, 2002). Saat ini pemanfaatan bahan pangan lokal di Indonesia masih tergolong kurang dibandingkan dengan Malaysia, Thailand dan Singapura, padahal dari segi ketersediaan dan keanekaragaman jenis bahan baku, Indonesia jauh lebih kaya dibandingkan negara pesaingnya tersebut (The Economist, 2018). Demi meningkatkan kualitas standar rantai pasokan dan menerapkan praktik pangan yang berkelanjutan, diperlukan adanya kerjasama multistakeholders, yaitu antara produsen di level grassroot, retailer, lembaga non-profit, organisasi petani, pemerintah hingga akademisi.

Upaya pemanfaatan sumber daya lokal berkelanjutan mulai populer dilakukan oleh produsen makanan organik, komunitas petani, dan pasar komunitas (Feldmann dan Hamm, 2015; Gruchmann et al, 2019). Di Provinsi Yogyakarta sendiri, telah muncul beberapa inisiatif pasar pangan sehat berbasis komunitas yang menjual bahan makanan organik lokal serta minim zat kimia. Kegiatan di pasar pangan tersebut tidak sebatas transaksi jual beli, tetapi juga proses edukasi hidup sehat yang dilakukan oleh produsen terhadap konsumennya. Namun karena keterbatasan sumber daya pengelola dan jumlah produsen pangan sehat yang relatif tidak banyak, pasar komunitas pangan sehat saat ini hanya dapat berjualan pada waktu dan lokasi tertentu. Senada dengan pernyataan Willer dan Lernoud (2016), bisnis makanan lokal masih tetap berada di dalam ceruk dan mengalami pertumbuhan yang terbatas karena integrasi dan koordinasi yang tidak memadai pada jaringan produksi pangan lokal dan juga sistem jaringan produksi pangan yang masih terdesentralisasi. Inisiatif yang lebih luas perlu dilakukan oleh para pemangku kepentingan untuk menggiatkan gerakan pasar pangan sejenis, bukan hanya untuk menyediakan akses makanan yang lebih sehat bagi masyarakat, namun juga untuk menstimulasi pergerakan ekonomi daerah, lokalitas, dan meningkatkan kelestarian lingkungan (Downs, 2017).

\section{METODE}

Penelitian ini dilakukan dengan pendekatan multi situs, pada Pasar Kamisan, Pasar Moncer, dan Pasar Mustokoweni yang berada di Yogyakarta. Ketiga pasar komunitas tersebut dipilih sebagai representasi dari pasar komunitas pangan sehat di Yogyakarta karena memiliki kesesuaian proposisi nilai secara umum yaitu menjual makanan sehat yang diproduksi menggunakan bahan lokal, dan mengedepankan edukasi hidup sehat terhadap konsumen. Triangulasi data dilakukan dalam bentuk data yang dikumpulkan pada waktu yang berbeda dan tempat yang berbeda untuk melawan pendapat bahwa penelitian tidak dapat direplikasi (Cassel et al, 2018; Walle, 2015). Untuk pengecekan keabsahan data dan menghindari bias yang terjadi dalam sebuah penelitian kualitatif, sesuai dengan pernyataan yang diungkapkan oleh Rahardjo (2017), dalam penelitian ini peneliti melakukan triangulasi temuan atau konfirmabilitas dengan cara mengkonfirmasi temuan dan gagasan kepada informan yang 
diwawancarai. Pengambilan data primer dengan cara wawancara mendalam dengan pihak pengelola komunitas dan observasi langsung pada kegiatan komunitas dilakukan pada bulan Mei 2019 hingga Juli 2019.

Metode analisis berikutnya adalah menggunakan sistem perencanaan visual berupa matriks SPOT. Alat ini memberikan iktisar mengenai strengths (kekuatan), problems (masalah), opportunities (peluang), dan threats (ancaman) yang dialami oleh suatu organisasi (Grove, 2011; Ati, 2019).

Hasil analisis pada model bisnis triple bottom line dan matriks SPOT ini, menjadi dasar dalam merancang inovasi model bisnis pada pasar komunitas makanan sehat. Kombinasi kedua alat analisis tersebut diharapkan dapat saling melengkapi dan digunakan untuk merancang peluang inovasi model bisnis melalui proses quick prototyping pada pasar komunitas di Yogyakarta, baik yang telah berjalan maupun untuk proses inisiasi pasar-pasar komunitas lainnya.

\section{HAIL DAN PEMBAHASAN}

Osterwalder dan Pigneur (2010) mengkategorikan model bisnis yang melampaui keuntungan berdasarkan sumber pendapatan menjadi dua kategori yaitu model pendanaan pihak ketiga dan model bisnis triple bottom line. Pada model pendanaan pihak ketiga, produk atau jasa dibayarkan oleh pihak ketiga seperti pemerintah atau donatur, namun penerima produk atau jasanya bukan pembayar. Model pendanaan pihak ketiga ini berisiko untuk tidak berfokus memberikan nilai kepada pihak yang membutuhkan, tetapi lebih menitikberatkan kepada penciptaan nilai kepada donatur karena keberlangsungan organisasi sangat bertumpu kepada sumbangan yang diberikan. Pada model bisnis triple bottom line, organisasi memiliki misi yang kuat pada permasalahan ekologi dan/atau sosial dan mengacu pada praktik akunting untuk lingkungan, sosial, dan biaya finansial. Model bisnis triple bottom line memiliki kanvas yang sedikit berbeda dengan model bisnis untuk bisnis dengan orientasi profit.
Pada model bisnis triple bottom line terdapat dua blok tambahan yang mengilustrasikan dua nilai keluaran, yaitu: 1) biaya sosial dan lingkungan dari sebuah model bisnis (dampak negatif), 2) manfaat positif pada lingkungan sosial dan ekologi dari suatu model bisnis (Osterwalder dan Pigneur, 2010: 265). Berikut merupakan analisis model bisnis kanvas dari model bisnis triple bottom line pada Pasar Kamisan, Pasar Moncer dan Pasar Mustokoweni.

\section{Proposisi Nilai Pasar Kamisan}

Nilai yang ditawarkan pasar Kamisan kepada pelanggan adalah pasar mingguan yang memperdagangkan komoditas pangan vegetarian lokal, baik yang belum diolah maupun yang siap untuk dikonsumsi dan juga kerajinan yang dibuat sendiri. UMKM yang berjualan di pasar Kamisan berjuang untuk menyediakan produk pangan yang segar (freshly produced), homemade dan menyehatkan kepada konsumennya. Produk vegetarian yang dimaksud adalah produk pangan yang bahan bakunya tidak menggunakan daging dan produk turunan daging, namun susu dan telur masih digunakan dalam beberapa produknya. Istilah organik dihindari dalam pelabelan produk pada pasar ini, karena dianggap membatasi ruang gerak para pelaku usaha yang jarang sekali mampu mengurus sertifikasi produk organik yang membutuhkan biaya relatif tinggi.

\section{Segmen Pelanggan Pasar Kamisan}

Secara garis besar, Pasar Kamisan melayani dua segmen pelanggan yang saling bergantung yaitu konsumen yang mengonsumsi produk dan pelaku usaha lokal sebagai pihak penyedia produk. Secara geografis, konsumen yang dibidik adalah orang-orang yang tinggal di Yogyakarta, juga wisatawan lokal maupun mancanegara yang datang dan membeli produk di pasar Kamisan. Dari sisi demografis, konsumen pasar Kamisan adalah individu dengan kisaran usia 18-55 tahun dari golongan ekonomi kelas menengah dan menengah ke atas. Keluarga, mahasiswa, dan pekerja muda 
yang memiliki kesadaran untuk menghidupi gaya hidup sehat dan vegetarian merupakan segmen pelanggan pasar ini secara psikografis. Produk pangan vegan dapat digolongkan sebagai produk pada pasar ceruk (niche market). Tetapi seiring dengan meningkatnya kesadaran masyarakat untuk menjaga pola hidup sehat, meminimalisir jejak ekologis (ecological footprint), dan kekejaman terhadap binatang (abstinence from animal cruelty), maka produk vegan akan dapat dikonsumsi oleh segmen pelanggan yang lebih luas.

Vendor yang tergabung di pasar Kamisan merupakan pelaku usaha yang berdomisili di provinsi Yogyakarta, menjual produk vegetarian, dan yang membuat produknya sendiri dengan bahan lokal. Penyalur produk (reseller) tidak termasuk dalam jenis usaha yang diperbolehkan untuk dilakukan pada pasar ini. Pelaku usaha yang tergabung di Pasar Kamisan diharapkan dapat menerapkan pengolahan produk yang ramah lingkungan, transparan, dan jujur.

\section{Saluran Pasar Kamisan}

Pasar Kamisan menjangkau pelanggannya dengan menyediakan produkproduknya pada setiap hari Kamis di Rumah Animalika Art \& Kitchen, Jalan Kaliurang KM 9,3. Komunitas ini juga kerap mengikuti berbagai bazar, pameran, dan event yang dilakukan oleh penyelenggara acara lain yang memiliki nilai sejalan dengan Pasar Kamisan.

\section{Hubungan Pelanggan Pasar Kamisan}

Selain menjual produk pangan sehat kepada konsumen, masing masing vendor di Pasar Kamisan juga tidak segan untuk memberi penjelasan mengenai bahan baku yang dipakai, mengedukasi konsumen untuk mengurangi penggunaan plastik, dan berbagai hal yang terkait dengan pola hidup sehat. Bila di kemudian hari konsumen ingin memesan produk kembali atau sekadar bertanya, vendor tentu siap memberikan bantuan personal melalui telepon dan Whatsapp. Pemberitahuan mengenai acara yang diadakan komunitas ini diunggah secara rutin di akun Instagram @pasarkamisan.
Namun promosi pada Instagram ini masih dianggap kurang efektif untuk menjangkau pelanggannya seperti yang diungkapkan oleh pengelola pasar sebagai berikut, "kalau untuk Instragram sendiri, saya tidak melihat adanya perkembangan yang bagus untuk peningkatan konsumen baru. Lebih banyak karena pasar ini sudah cukup lama, namanya sudah cukup dikenal dan masing masing orang yang pernah bersentuhan dengan pasar Kamisan biasanya akan merekomendasikan kepada teman lainnya supaya kalau nanti main ke Jogja datang ke sini saja. Hal yang membuat mereka loyal adalah produk kami dianggap bagus dan berkualitas. Mulai dari rasa, bahan, tingkat kepercayaan dalam artian bisa terlacak itu mereka sangat percaya (Wibowo, wawancara personal, 2019)". Mengenai penambahan anggota vendor baru, komunitas tetap mengandalkan cara promosi konvensional yaitu dengan sistem getok tular (word of mouth) yang dianggap masih efektif.

\section{Arus Pendapatan Pasar Kamisan}

Sebagai organisasi non-profit, arus pendapatan utama Pasar Kamisan berasal dari iuran yang dibayarkan oleh masing masing vendor yaitu sebesar Rp30.000 per bulan. Bagi konsumen yang datang ke pasar Kamisan tidak dikenakan biaya retribusi, hanya membayar seharga produk yang dibeli kepada vendor.

\section{Sumber Daya Utama Pasar Kamisan}

Sumber daya utama dari Pasar Kamisan adalah manajemen dan pengelolaan platform pasar ini sendiri, sehingga memungkinkan pelaku usaha dan konsumen yang memiliki nilai-nilai serupa dapat saling bertemu. Sumber daya fisik yang dimiliki Pasar Kamisan masih tergolong sederhana, seperti meja, kursi, dan alat-alat kebersihan.

\section{Aktivitas Kunci Pasar Kamisan}

Saat ini aktivitas utama yang dilakukan oleh pengelola adalah mengadakan event rutin Pasar Kamisan dan mengikuti acara pameran atau bazar serupa. Upaya untuk meningkatkan kualitas dan kapasitas 
vendor juga menjadi perhatian utama oleh komunitas ini yang diwujudkan dengan adanya kegiatan quality control, melakukan rapat koordinasi, dan memberikan pelatihan (training). Pengelola pasar sangat membuka peluang bagi pelaku UMKM baru untuk bergabung sebagai vendor, dengan syarat usaha memiliki nilai yang sejalan dengan Pasar Kamisan, lolos proses kurasi, dan produknya cukup berbeda dengan vendor yang sudah ada saat ini.

\section{Kemitraan Utama Pasar Kamisan}

Mitra utama Pasar Kamisan adalah penyedia lokasi pasar yaitu Animalika Art \& Kitchen yang menyewakan tempat bagi komunitas dengan harga bersahabat. Pemilik tempat Animalika Art \& Kitchen, kerap menawarkan peluang kerja sama dengan penyelenggara pameran yang dapat dimanfaatkan oleh Pasar Kamisan. Pasar komunitas lain yang berada di Yogyakarta juga tidak dianggap saingan, bahkan menjadi partner kolaborasi untuk mengadakan acara dan berjualan bersama. Sekolah Pagesangan dan Kebun Organik Dowa merupakan contoh komunitas desa yang berkolaborasi sekaligus menjadi vendor di Pasar Kamisan.

Sebagai upaya peningkatan kapasitas vendor, komunitas juga menjalin kerjasama dengan fasilitator eksternal, seperti dengan pihak credit union yang memberikan wawasan mengenai literasi keuangan (financial literacy). "Selain itu kita juga punya beberapa channel lain yang biasa kita undang sebagai fasilitator UMKM. Dulu kami sempat didatangi oleh seorang pakar kuliner, yaitu William Wongso yang melakukan review terhadap produk pangan, kemudian teman-teman diberi masukan tentang cara pengolahan makanan, wawasan tentang pengemasan dan memberikan encouragement kepada anggota komunitas (Wibowo, wawancara personal, 2019)".

\section{Struktur Biaya Pasar Kamisan}

Komponen biaya tetap yang dikeluarkan oleh komunitas adalah biaya sewa tempat. Iuran yang dibayarkan oleh vendor juga dimanfaatkan untuk membayar biaya listrik, biaya perawatan infrastruktur, dan sebagai kas komunitas. Kas tersebut lebih dipergunakan untuk mendanai acara kekeluargaan komunitas, seperti untuk menyumbang kepada vendor yang sedang sakit atau berduka.

\section{Manfaat Sosial dan Lingkungan Pasar Kamisan}

Blok manfaat lingkungan pada model bisnis triple bottom line dianalisis untuk menilai bagaimana organisasi menghasilkan lebih banyak dampak positif bagi lingkungan dibandingkan dengan dampak negatifnya (Joyce dan Paquin 2016). Vendor di Pasar Kamisan tidak menggunakan minyak sawit dalam proses pengolahan produknya, digantikan dengan minyak kelapa. Komunitas Pasar Kamisan peduli dengan persoalan sawit, yang menyebabkan masalah deforestasi, punahnya habitat alami orangutan, dan rusaknya kualitas tanah yang pernah ditanami tumbuhan sawit. Minyak kelapa digunakan sebagai alternatif bahan pengganti minyak sawit karena merupakan produk lokal sehingga mudah diakses olehpara pelaku usaha.

Manfaat sosial berbicara tentang aspek misi organisasi yang berfokus terhadap penciptaan dampak baik bagi para pemangku kepentingan dan masyarakat yang lebih luas. Nilai sosial yang ingin diciptakan oleh komunitas adalah memangkas rantai pasokan (supply chain) pada perdagangan pangan. Hal ini dilakukan bukan untuk menurunkan harga, tetapi lebih memberikan harga yang adil (fair trade) bagi produsen dan konsumen. Masalah utama yang dihadapi oleh petani dan pelaku usaha adalah produknya kerap dibeli dengan harga rendah oleh tengkulak atau pengepul. Namun hal ini harus tetap dilakukan agar produknya bisa terjual. Dengan adanya komunitas Pasar Kamisan, pelaku usaha dapat menjual produknya dengan harga yang pantas dan juga menjamin kualitas produknya memang baik bagi kesehatan konsumen. 
Biaya Sosial dan Lingkungan Pasar Kamisan

Saat ini, vendor Pasar Kamisan hanya dapat meminimalisir penggunaan plastik dan kertas namun belum bisa menggantikannya secara total karena masih belum menemukan bahan alternatif yang tepat.

\section{Pasar Moncer}

Pasar Moncer merupakan pasar komunitas UMKM yang diadakan secara mingguan di kantor Dinas Perindustrian dan Perdagangan Yogyakarta. Saat ini kurang lebih sebanyak 145 UMKM pernah berjualan di acara yang diadakan komunitas ini. Berikut merupakan pemaparan model bisnis kanvas pada Pasar Moncer.

\section{Proposisi Nilai Pasar Moncer}

Anindita Safitri, pendiri Pasar Moncer mulanya prihatin terhadap kesulitan yang dihadapi petani organik lokal dalam hal penjualan produknya karena harga yang kalah kompetitif dibandingkan produk pangan yang mengandung bahan kimia pada umumnya. Di sisi lain, kebutuhan akan pangan sehat sebenarnya sudah mulai banyak diminati oleh konsumen namun pada umumnya produk pangan sehat yang beredar di Indonesia masih merupakan produk impor dengan harga yang mahal. Pasar Moncer mencoba hadir sebagai solusi bagi masalah tersebut.

Keunikan Pasar Moncer adalah adanya sistem kurasi produk maupun sumber daya manusia yang harus dilewati UMKM sebelum bergabung di komunitas ini untuk memastikan bahwa produknya memang layak dan sehat bagi konsumen. Kriteria pangan sehat menurut Pasar Moncer merupakan produk yang tidak mengandung bahan kimia penguat rasa, pewarna buatan, pengawet dan gluten. Penerapan aturan bebas gluten (gluten free) dan hanya menggunakan bahan lokal pada produk pangan yang dijual merupakan bentuk upaya komunitas ini untuk meningkatkan ketahanan pangan pada daerah setempat. Pasar Moncer ingin menunjukkan kepada masyarakat bahwa makanan sehat itu harganya terjangkau, rasanya enak, dan jenisnya beragam.

Proposisi nilai yang ditawarkan bagi para UMKM adalah terciptanya hubungan yang saling menguntungkan bukan hanya antara pedagang dengan konsumennya, namun juga dengan antar penjual yang berdinamika dalam komunitas pasar ini. Pengelola Pasar Moncer, Safitri (2019) menyatakan bahwa, "Kekerabatan di Pasar Moncer cukup kuat sehingga terjadi simbiosis mutualisme di antara para pedagang, contohnya ada tenant yang menjual nasi sorghum, lalu peyeknya dibeli dari temannya sendiri dalam komunitas ini. Setiap tenant bertanggung jawab untuk setidaknya menggaet satu petani organik atau petani lokal. Bahkan ketika suatu produk belum terjual pada konsumen di luar komunitas, menjual diantara penjual saja juga sudah saling menguntungkan".

\section{Segmen Pelanggan Pasar Moncer}

Segmen pelanggan Pasar Moncer adalah individu yang telah memiliki kesadaran tentang pentingnya pola hidup sehat. Ceruk pasar yang dibidik komunitas ini adalah, sekolah untuk anak anak berkebutuhan khusus, dokter dan para orangtua dari anak autis yang perlu mengonsumsi makanan dengan kriteria tertentu. Bahan kimia dan gluten merupakan kandungan yang dapat memperberat gangguan interaksi sosial, komunikasi, perilaku, gangguan sensorik dan motorik pada anak autis, sehingga sangat harus dihindari untuk dikonsumsi.

\section{Saluran Pasar Moncer}

Saat ini kegiatan Pasar Moncer dilakukan secara rutin tiga kali dalam seminggu yaitu di kantor Dinas Perindustrian dan Perdagangan Yogyakarta, Taman Budaya Yogyakarta, dan Museum Pusat TNI Angkatan Udara Dirgantara Mandala. Saluran tersebut dapat digolongkan sebagai saluran langsung karena saat acara dilaksanakan vendor yang tergabung dalam Pasar Moncer berinteraksi secara langsung dengan konsumen yang hadir. 


\section{Hubungan Pelanggan Pasar Moncer}

Hubungan antara tenant dengan konsumen yang dibangun adalah dalam bentuk bantuan personal. Para pelaku UMKM yang tergabung dalam Pasar Moncer secara aktif menyebarkan pemberitahuan tentang kegiatan Pasar Moncer kepada pelanggannya masing-masing, sehingga pemasaran kegiatan ini dapat meluas. Pengelola komunitas juga kerap mengadakan promo belanja bagi konsumennya dalam bentuk voucher belanja atau tiket nonton bioskop yang membuat para pembeli semakin senang dan tertarik untuk berbelanja di Pasar Moncer.

\section{Arus Pendapatan Pasar Moncer}

Pendapatan utama Pasar Moncer berasal dari persentase penjualan yang dibayarkan oleh tenant pada setiap akhir acara. Besaran persentase yang diberikan tidak ditetapkan oleh pengelola Pasar Moncer, namun murni sukarela dari para anggotanya. Sesekali ketika penjualan sedang sepi, Pasar Moncer juga memperbolehkan anggotanya untuk tidak membayar biaya apapun bagi komunitas.

\section{Sumber Daya Utama Pasar Moncer}

Salah satu hal yang membedakan Pasar Moncer dengan pasar komunitas lainnya adalah terkait dengan sumber daya intelektual yang dimiliki yaitu adanya database UMKM dan sistem pengelolaan yang unik. Saat ini pengelola komunitas sedang dalam proses pengurusan hak paten mengenai sistem pengelolaan maupun logo Pasar Moncer. Database UMKM yang dimiliki komunitas, berisi informasi mengenai UMKM yang pernah mengikuti acara Pasar Moncer, produk yang dijual, dan perizinan usaha yang dimilikinya.

\section{Aktivitas Kunci Pasar Moncer}

Aktivitas kunci yang perlu dilakukan Pasar Moncer untuk mewujudkan proposisi nilainya adalah meliputi kegiatan kurasi terhadap UMKM, kegiatan berjualan dan pameran, kegiatan koordinasi antara pengelola dengan tenant, manajemen komunitasdan quality control. Pengelola komunitas mengungkapkan bahwa kegiatan kurasi sangat penting dilakukan untuk menjaga kualitas produk yang dijual di Pasar Moncer. "Teman teman UMKM rata rata belum punya prosedur operasional standar, jadi setiap akan ada event harus ada kurasi lagi. Pengalaman kami paling tidak kalau sudah lima kali lolos kurasi berturut turut baru mereka bisa memiliki SOP (standard operational procedure). Kalau tidak nanti ketika kurasi rasanya enak tetapi ketika hari $\mathrm{H}$ terdapat perbedaan harga dan kualitas. Jadi menurut kami UMKM perlu memiliki SOP, lebih berkomitmen, dan bersikap profesional (Safitri, 2019)".

\section{Kemitraan Utama Pasar Moncer}

Mitra utama yang mendukung berjalannya Pasar Moncer ini adalah berbagai pihak pemerintah yaitu dari Dinas Perindustrian \& Perdagangan (Disperindag) yang menyediakan lokasi berjualan pasar, Pusat Layanan Terpadu (PLUT) yang memberikan pendampingan bagi para anggota komunitas, dan Badan Pengawas Obat \& Makanan (BPOM) yang membantu dalam proses kurasi. Kerja sama dengan pihak pemerintah banyak menguntungkan angota komunitas dalam proses pengurusan izin usaha sehingga prosesnya dapat lebih cepat bahkan mendapat bantuan biaya subsidi. Pasar Moncer juga menjalin kemitraan dengan para ahli gizi, Politekes gizi, dan beberapa pelaku bisnis sukses untuk membina dan memberi saran bagi peningkatan kualitas anggota komunitasnya. Pada bidang publikasi, komunitas ini kerap bekerjasama dengan Womenwill Yogyakarta untuk menyebarkan informasi mengenai acara yang diadakan oleh Pasar Moncer.

\section{Struktur Biaya Pasar Moncer}

Komponen biaya variabel pada Pasar Moncer, meliputi biaya tenaga kerja lepas yang membantu menjadi kasir ketika acara berlangsung, biaya kebersihan, dan keperluan operasional lainnya. Dapat dikatakan bahwa komponen biaya tetap yang dibayarkan komunitas hampir tidak ada, karena untuk 
biaya sewa tempat telah digratiskan oleh pihak pemerintah.

\section{Manfaat Sosial dan Lingkungan Pasar Moncer}

Dampak baik yang ditimbulkan dengan adanya Pasar Moncer adalah terbantunya UMKM dalam mengurus perizinan usahanya dan mendapat akses kepada pasar yang lebih luas dibandingkan dengan tanpa adanya komunitas ini. Beberapa UMKM yang pernah berjualan di Pasar Moncer, telah mendapatkan kesempatan untuk menjual produknya hingga pasar internasional dikarenakan oleh kualitasnya yang baik dan izin usahanya juga sudah memenuhi standar yang ada. Bagi konsumen, Pasar Moncer juga berupaya untuk menyediakan akses kepada makanan sehat dengan rasa yang enak dan harga yang pantas.

\section{Biaya Sosial dan Lingkungan Pasar Moncer}

Walaupun pemakaian plastik sebagai kemasan telah sangat diminimalisir pemakaiannya pada komunitas ini, namun ada beberapa penggunaan plastik yang belum dapat digantikan seperti sendok plastik, dan plastik kecil untuk tempat sambal.

\section{Proposisi Nilai Pasar Mustokoweni}

Blok bangunan proposisi nilai memberi gambaran mengenai layanan dan/atau produk yang ditawarkan organisasi dalam rangka menjawab kebutuhan pelanggannya dan lebih unggul dibandingkan dengan penawaran organisasi lainnya (Osterwalder \& Pigneur, 2010; Downs, 2017). Awal mulanya Pasar Mustokoweni didirikan untuk menjadi wadah bertemunya para pecinta makanan sehat dengan beberapa artisan kuliner yang belum memiliki tempat berjualan tetap. Pada acara yang diadakan, konsumen dan penjual diharapkan dapat berinteraksi dalam suasana kekeluargaan dan bertukar informasi mengenai produk pangan maupun pola hidup sehat.

Pendiri dan pengelola Pasar Mustokoweni, Prasetyo (2019) menyatakan bahwa saat ini banyak produk pangan yang beredar di pasaran namun tidak terdapat keterangan yang jelas mengenai jenis bahan baku dan komposisi yang digunakan. Penyediaan informasi mengenai bahan baku pada produk pangan dapat membantu konsumen untuk memutuskan bahwa produk tersebut cukup aman atau tidak untuk dikonsumsi (Stella, 2019). Kurangnya transparansi informasi tentang komposisi bahan pangan dapat menciptakan titik buta (blind spot) pada rantai pasokan dan membuat konsumen terpapar pada risiko yang tidak perlu. Pasar Mustokoweni memungkinkan konsumen untuk menggali informasi sejelas-sejelasnya mengenai makanan yang dibeli dengan bertanya langsung dengan pembuatnya, di sisi lain tenant juga diharapkan untuk memberikan informasi yang jujur dan lengkap kepada konsumennya.

Produk yang dijual di Pasar Mustokoweni mayoritas merupakan produk pangan sehat siap konsumsi tanpa menggunakan penguat rasa dan pengawet dari bahan kimia. Tugas utama tenant Pasar Mustokoweni adalah mengedukasi konsumen bahwa makanan yang menggunakan bahanbahan alami dan ramah lingkungan selain baik dikonsumsi untuk kesehatan jangka panjang juga memiliki cita rasa yang enak tidak kalah dengan makanan dengan penguat rasa kimiawi.

\section{Segmen Pelanggan Pasar Mustokoweni}

Pasar Mustokoweni menerapkan strategi pemasaran terkonsentasi untuk para ibu muda, anak muda juga keluarga dengan kelas ekonomi menengah dan menengah atas yang memiliki atensi khusus terhadap produk pangan sehat. Karakteristik psikografis untuk segmen pelanggan tersebut umumnya berpendapat bahwa kejelasan informasi pada kemasan produk merupakan aspek penting yang mempengaruhi keputusan pembelian, menyukai produk natural melakukan perencanaan konsumsi bagi keluarganya, suka memasak, dan memilih untuk menggunakan bahan pangan dari negaranya sendiri (Van Huy, 2019). Selain bagi para pecinta pola hidup sehat, Pasar Mustokoweni 
juga ingin menjangkau konsumen dari berbagai kalangan bahkan bagi orang yang belum memiliki wawasan mengenai hidup sehat sekalipun. Artisan yang menjadi vendor pada komunitas ini bertanggungjawab untuk mengedukasi konsumennya. Definisi artisan yang dimaksudkan adalah pelaku usaha yang membuat produknya sendiri dan masih dengan skala produksi yang kecil (Prasetyo, 2019).

\section{Saluran Pasar Mustokoweni}

Pasar Mustokoweni menyalurkan proposisi nilai komunitasnya melalui kegiatan berjualan berkala setiap minggu kedua dan minggu keempat tiap bulannya di Mustokoweni Heritage Hotel, Yogyakarta. Bila ada kesempatan dan dirasa memiliki nilai yang sejalan, para vendor pasar Mustokoweni juga kerap mengikuti bazar yang diadakan oleh penyelenggara acara lain.

\section{Hubungan Pelanggan Pasar Mustokoweni}

Beberapa pendorong utama untuk mempertahankan hubungan dengan pelanggan meliputi kegiatan akuisisi, yang merupakan tindakan mendatangkan pelanggan baru; retensi, yang berfungsi untuk mempertahankan pelanggan yang sudah ada; dan peningkatan penjualan, yang mendorong pelanggan untuk membeli lebih banyak produk (Osterwalder \& Pigneur, 2010). Pasar Mustokoweni memberikan bantuan personal bagi konsumennya dalam wujud konsultasi langsung yang diberikan oleh vendor kepada pengunjung yang datang. Pengumuman terkait dengan acara-acara yang akan diadakan oleh komunitas ini diunggah di akun Instagram @ pasarmustokoweni dan disebarkan melalui aplikasi Whatsapp. Prasetyo (2019) berpendapat bahwa menghubungi konsumen langsung melalui jalur pribadi Whatsapp itu lebih efektif dibandingkan hanya melalui unggahan pada media sosial. Mayoritas pengikut akun Instagram Pasar Mustokoweni berasal dari luar kota, sehingga rata-rata hanya menonton unggahannya saja namun tidak hadir ke acara. Para vendor berupaya untuk mengelompokkan konsumennya berdasarkan minat dan hobi yang dimiliki, sehingga informasi yang diberikan dapat lebih sesuai dengan keinginan konsumen.

\section{Arus Pendapatan Pasar Mustokoweni}

Saat ini arus pendapatan utama Pasar Mustokoweni adalah berasal dari iuran yang dibayarkan oleh para vendor yaitu sebesar Rp30.000 per bulan untuk dua kali acara. Konsumen yang datang tidak dikenakan biaya masuk, mereka hanya membayar senilai harga produk yang dibelinya kepada vendor.

\section{Sumber Daya Utama Pasar Mustokoweni}

Sumber daya fisik yang digunakan pada aktivitas operasional Pasar Mustokoweni adalah berupa meja dan kursi. Selain itu sumber daya utama komunitas ini adalah para pelaku usaha yang selain menjual produk makanan sehat, mereka juga memiliki tanggung jawab moral untuk melakukan edukasi mengenai pola hidup sehat dan berkelanjutan kepada konsumen.

\section{Aktivitas Kunci Pasar Mustokoweni}

Aktivitas utama komunitas ini adalah pengelolaan platform yang menghubungkan para artisan dengan konsumennya dan kegiatan pengembangan platform untuk senantiasa menciptakan permintaan pada pasar. Rapat koordinasi antara pengurus komunitas dengan vendor biasanya diadakan setiap dua bulan sekali untuk mendiskusikan masalah yang ada dan meluruskan kembali visi misi yang dianut bersama. Kegiatan pencatatan keuangan dan promosi acara komunitas dilakukan secara terpusat oleh pengelola.

Pada minggu keempat setiap bulannya, selain mengadakan penjualan reguler, Pasar Mustokoweni juga kerap menggelar acara lokakarya gratis dengan berbagai tema seputar pola hidup sehat. Narasumber yang mengisi workshop itu dapat berasal dari pihak internal yaitu para tenant Pasar Mustokoweni maupun para pelaku usaha di luar komunitas. "Ini merupakan momen kepada teman-teman di luar Mustokoweni untuk space bagi mereka 
kalau ada yang mau presentasi atau mau mengadakan workshop secara putus bukan tergabung di pasar Mustokoweni. Workshopitu tujuannya untuk mengedukasi. Banyak orang yang malas ke pasar karena harus belanja. Workshop ini diadakan khusus untuk orang-orang yang ingin mencari ilmunya tapi tidak ingin belanja (Prasetyo, 2019)".

\section{Kemitraan Utama Pasar Mustokoweni}

Mitra utama komunitas ini adalah pemilik lokasi Mustokoweni the Heritage Hotel yang dengan sukarela menyediakan tempat berjualan bagi para artisan yang ada. Pemilik lokasi juga berperan penting dalam memberikan opini dan saran yang obyektif bagi peningkatan kualitas komunitas. Dalam rangka menciptakan layanan yang variatif bagi konsumennya, pengelola menjalin kemitraan denganpara pelaku usaha di luar komunitas untuk sesekali berbagi pengetahuan dan berjualan di Pasar Mustokoweni.

\section{Struktur Biaya Pasar Mustokoweni}

Pengeluaran utama Pasar

Mustokoweni adalah untuk membiayai biaya kebersihan dan biaya sewa lahan parkir di sekitar lokasi usahanya. Bila ada sisa uang, biasanya pengelola akan memasukkannya ke dalam kas komunitas atau membuat voucher belanja yang dapat digunakan oleh para vendor.

\section{Manfaat Sosial dan Lingkungan Pasar Mustokoweni}

Kehadiran Pasar Mustokoweni diharapkan secara bertahap dapat meningkatkan kesadaran baik para pelaku usaha dan konsumen untuk meninggalkan praktik usaha yang tidak ramah lingkungan. Mengenai permasalahan sampah plastik, vendor pada komunitas ini berupaya untuk menggunakannya seminimal mungkin. "Masalah sampah kita perlu proses agak lama karena menyangkut banyak orang yang belum tentu semuanya berada di tahap kesadaran yang sama. Teman teman vendor ada beberapa yang bergabung ke pasar dengan produknya yang tidak sesempurna sekarang tapi kita terima karena kita lihat dia mau berkembang dan mau menerima masukan. Seperti dia masuk dan pakai produk sayur, itu kita sarankan coba deh pakai sayur organik. Masukan dari pendatang dari konsumen juga kita terima. Proses sih, ketika dibilang pasar organik itu sebenarnya bukan hanya tentang produknya tapi kan juga berkembang dari sisi prosesnya juga. (Prasetyo, 2019)".

Komunitas Pasar Mustokoweni berkomitmen untuk memperpendek rantai pasokan dengan cara hanya menggunakan bahan pangan yang dibeli langsung dari petani lokal atau dari koperasi yang dikelola penduduk. Dampak sosial lain yang dihasilkan oleh komunitas ini adalah harga adil bagi para vendor dengan menerapkan strategi pemasaran diferensiasi pada produknya.

\section{Biaya Sosial dan Lingkungan Pasar Mustokoweni}

Pasar Mustokoweni ini diikuti oleh 24 vendor artisan dan didatangi oleh kurang lebih 50 hingga 100 pengunjung setiap acaranya. Karena pemakaian plastik masih digunakan oleh beberapa vendor, makakegiatan pasar ini masih menyisakan sampah plastik walaupun sudah sangat diminimalisir jumlahnya. "Kami tidak bisa idealis tidak boleh pakai plastik sama sekali. Kembali lagi kita tidak bisa memaksakan orang yang belum punya pemahaman, karena nantinya hanya akan dijalankan dengan setengah hati. Pelan-pelan diingatkan dan dicari solusi bersama untuk masalah sampah plastik dengan mencari mekanisme penjualan atau bahan alternatif yang lebih ramah lingkungan dengan harga yang tetap ekonomis (Prasetyo, 2019)".

Berdasarkan analisis SPOT pada blok bangunan model bisnis pasar komunitas yang telah dilakukan, dapat dirumuskan pula beberapa alternatif strategi yang dapat dilakukan oleh organisasi. Hasil matriks SPOT bagi pasar komunitas yang telah beroperasi tersaji dalam gambar 1 . 


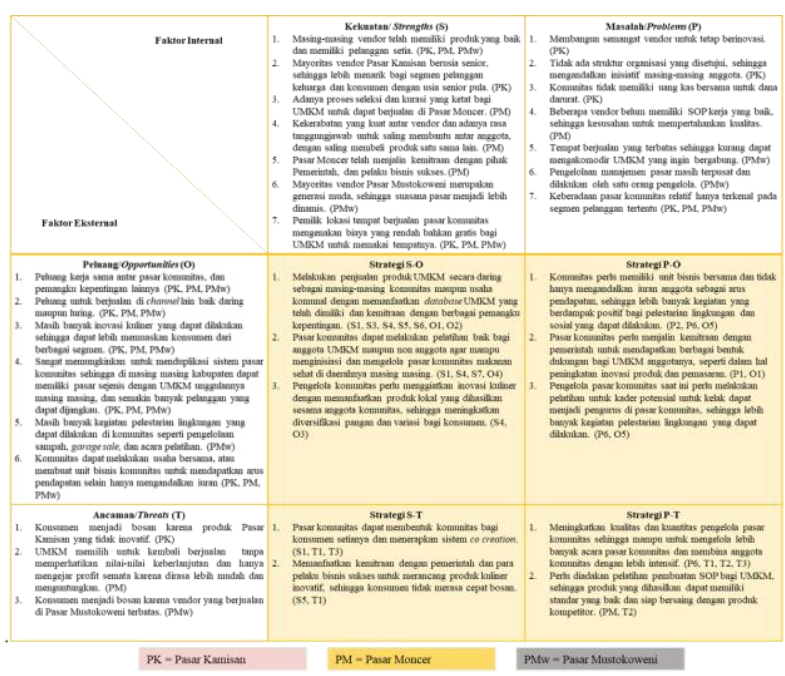

Gambar 1. Matriks SPOT pada Pasar Komunitas Makanan Sehat

\section{Inovasi Model Bisnis Triple Bottom Line padaPasar Komunitas Makanan Sehat}

Inovasi model bisnis berkaitan erat dengan bidang ekonomi dan manajemen operasi yang dapat diaplikasikan secara universal pada berbagai jenis industri.

Organisasi yang ingin merancang solusi berkelanjutan, mengurangi ketidakefisienan, dan meningkatkan kinerja dapat melakukan observasi terhadap blok bangunan model bisnis tertentu yang memerlukan perbaikan. Ketidakefisienan dalam konteks berkelanjutan seringkali disebabkan oleh ketidakseimbangan penyelarasan kepentingan antar para stakeholders dan berbagai eksternalitas yang ditimbulkan (Girotra \& Netessine, 2013). Berdasarkan pemetaan matriks SPOT pada kanvas model bisnis pasar komunitas, dapat disimpulkan beberapa gagasan penyempurnaan bagi sistem organisasi. Alternatif saran yang diberikan dapat diterapkan oleh masing-masing pasar komunitas maupun sebagai model bisnis bagi inisiator lainnya yang ingin membentuk pasar komunitas serupa. Inovasi model bisnis triple bottom line bagi pasar komunitas makanan sehat dipaparkan pada Gambar 2.

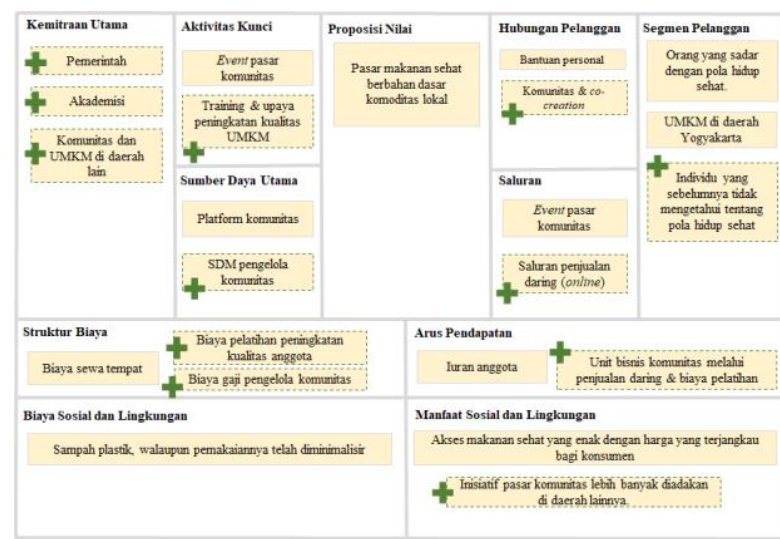

Gambar 2: Inovasi Model Bisnis Triple Bottom Line pada Pasar Komunitas Makanan Sehat

Hal yang cukup perlu mendapat perhatian pengelola adalah mengenai sistem manajemen organisasi sebaiknya tidak hanya bertumpu pada satu atau segelintir orang, namun perlu ada pendelegasian tanggung jawab dan pembagian kerja manajerial yang efektif. Saat ini yang menjadi pengurus pasar komunitas merupakan beberapa orang yang memiliki jiwa wirausaha sosial dan secara suka rela mengkoordinir UMKM anggota komunitas lainnya untuk berjualan bersama. Penambahan staf pengurus masih menjadi kendala, karena dikhawatirkan akan terjadi konflik kepentingan atau kebijakan yang memihak apabila pengurus berasal dari internal anggota komunitas sendiri. Namun apabila dibiarkan, masalah keterbatasan sumber daya manusia dalam manajemen ini dikhawatirkan dapat menghambat perkembangan organisasi bahkan mengancam keberlanjutan pasar komunitas ini. Alternatif tindakan yang dapat diambil pihak pengelola adalah merekrut tenaga kerja internal maupun eksternal, melakukan pelatihan bagi kader potensial, dan untuk lebih memotivasinya organisasi perlu memberikan kompensasi kerja yang pantas bagi pengelola komunitas. Bila sumber daya manusia untuk mengelola organisasi telah mencukupi, diharapkan komunitas dapat menginisiasi program pelestarian lingkungan maupun pemberdayaan masyarakat yang lebih optimal karena tidak ada penumpukan beban kerja yang terlalu berat bagi sebagian orang. Para inisiator pasar komunitas dapat lebih fokus untuk mengerjakan hal yang 
sifatnya strategis, bukan terbebani dengan hal teknis semata. Blok bangunan pada model bisnis yang terpengaruh pada kegiatan ini adalah pada blok aktivitas kunci dan sumber daya kunci yaitu sumber daya manusia pengelola komunitas yang berkualitas.

Salah satu hal yang menjadi kekhawatiran pengelola organisasi adalah seiring berjalannya waktu konsumen akan bosan dengan produk yang ditawarkan pasar komunitas makanan sehat karena tidak variatif dan kurang inovatif. Banyak pelaku UMKM masih menganggap aktivitas pembelajaran untuk meningkatkan kapasitas usaha merupakan upaya tambahan yang membutuhkan banyak waktu dan merepotkan, sehingga mereka lebih fokus kepada kegiatan usaha sehari-hari dan mengenyampingkan upaya peningkatan kualitas usahanya (Pucihar et al, 2019). Hal ini juga terjadi pada vendor di pasar komunitas, pengelola merasa agak kesulitan untuk memotivasi anggota komunitasnya untuk melakukan inovasi produk, umumnya karena vendor tersebut telah merasa nyaman dengan produk yang dihasilkannya saat ini. Untuk mengatasi hal tersebut pengelola komunitas dapat bekerjasama dengan pemerintah maupun pelaku bisnis yang telah berhasil untuk bersama-sama mengadakan program pelatihan, seminar, dan pendampingan kepada UMKM. Materi pelatihan yang perlu diberikan adalah terkait inovasi produk, strategi pemasaran, pembuatan standard operational procedures, dan materi lainnya yang dapat meningkatkan kualitas usaha para anggota komunitas. Kerja sama dengan pemerintah diharapkan dapat menawarkan informasi, staf terampil, akses terhadap perluasan jangkauan pasar, dan insentif yang menguntungkan bagi pelaku UMKM pangan sehat.

Sebagai upaya untuk menjaga hubungan yang berkelanjutan dengan konsumen, organisasi sebaiknya memfasilitasi para pelanggan setia untuk saling terkoneksi dalam bentuk komunitas konsumen produk pangan lokal dan sehat. Banyak perusahaan mempertahankan komunitas daring yang memungkinkan pengguna untuk bertukar pengetahuan, memecahkan masalah satu sama lain dan juga dapat membantu perusahaan lebih memahami pelanggan mereka (Osterwalder \& Pigneur, 2010). Kegiatan co-creation yang melibatkan pelanggan untuk merancang produk kuliner yang inovatif dapat pula diterapkan pada komunitas pelanggan pasar makanan sehat, sehingga produk yang dibuat oleh para vendor memang benar-benar sesuai keinginan dan selera konsumen.

Keberlanjutan organisasi yang bersifat nirlaba sangat rentan untuk terganggu apabila sumber dana yang dimiliki hanya tergantung pada bantuan donor, sumbangan, atau sumber dana eksternal lainnya. Hal ini berbeda dengan bentuk perusahaan sosial (social enterprises) yang bukan hanya bertujuan untuk menciptakan dampak positif pada lingkungan alam dan sosial, tetapi juga menjaga kelayakan finansial pada kegiatan operasinya (Rahdari et al, 2016). Pasar komunitas makanan sehat saat ini mengandalkan iuran anggota sebagai satusatunya arus pendapatan organisasi. Dalam rangka menjaga keberlanjutan usaha dan memperkuat kondisi keuangan organisasi, pasar komunitas perlu mempertimbangkan sumber pendapatan lain seperti membentuk unit bisnis bersama, membuka saluran penjualan daring (online), mengadakan pelatihan berbayar terkait pembuatan produk makanan sehat atau pelatihan dengan tema keberlanjutan pangan lainnya yang dapat disampaikan oleh para UMKM anggota komunitas. Blok bangunan model bisnis yang terpengaruh oleh adanya penambahan channel penjualan dan sumber pemasukan baru adalah bagian blok saluran dan arus pendapatan.

Pada praktiknya pasar komunitas telah berkontribusi dalam penyediaan makanan sehat bagi konsumen dan merangsang UMKM untuk melakukan produksi pangan yang lebih berkelanjutan. Namun para pengelola komunitas saat ini masih merasa bahwa pasar pangan sehat belum dapat melayani segmen pelanggannya secara optimal. Jangkauan pelanggan pasar komunitas dapat dikatakan masih merupakan 
ceruk pasar dan belum mampu menjadi produk unggulan komoditas daerah. Upaya untuk mencapai rantai pasok pangan berkelanjutan memang tidak akan cukup bila hanya mengandalkan aksi segelintir orang. Inisiatif multi-stakeholder yang melibatkan peran pemerintah, petani, akademisi, dan komunitas akan menghasilkan dampak positif yang lebih besar dibandingkan upaya yang dilakukan secara terpisah (Sustainable Food Laboratory, 2005). Karenanya pasar komunitas perlu melakukan inisiatif bersama (joint initiatives) dengan pemangku kepentingan lainnya untuk menjadikan pangan sehat sebagai produk komoditas dan dikenal secara lebih luas oleh masyarakat. Dengan bekerjasama dengan akademisi, komunitas makanan sehat dan pelaku usaha yang berada di daerah lain, para pemangku kepentingan dapat saling bertukar informasi mengenai pengetahuan teknis, wawasan mengenai realita di lapangan, dan solusi masalah dengan biaya rendah yang masih sulit untuk dituntaskan. Sangat diharapkan apabila muncul inisiatif pasar komunitas makanan sehat yang baru di masing-masing kabupaten dengan UMKM unggulannya sebagai anggota.

\section{Kesimpulan}

Berdasarkan hasil penelitian pada pasar komunitas makanan sehat, dapat disimpulkan bahwa organisasi perlu melakukan inovasi pada beberapa blok bangunan model bisnis triple bottom line yang dimiliki. Strategi alternatif utama yang disarankan melibatkan inovasi pada 9 blok bangunan model bisnis pasar komunitas, yaitu: 1) Menambah jumlah pengelola pasar komunitas (blok bangunan sumber daya utama), 2) Melakukan pelatihan berkala untuk menjaga kualitas para pengurus dan anggota komunitas (blok bangunan aktivitas kunci), 3) Kompensasi upah bagi pengelola pasar komunitas (blok bangunan struktur biaya), 4) Menjalin kemitraan dengan pemangku kepentingan yang lebih luas (blok bangunan kemitraan utama), 5) Membentuk komunitas pelanggan dan merangsang kegiatan co-creation (blok bangunan hubungan pelanggan), 6) Membuat saluran penjualan daring (blok bangunan saluran), 7) Membentuk unit bisnis dan mendapat penghasilan tambahan dari pelatihan berbayar (blok bangunan arus pendapatan), 8) Memperluas jangkauan segmen pelanggan (blok bangunan segmen pelanggan), 9) Merangsang munculnya pasar komunitas makanan sehat lain di berbagai daerah (blok bangunan manfaat sosial dan lingkungan).

Untuk menemukan model bisnis yang tepat, selanjutnya para pemangku kepentingan tetap perlu melakukan eksperimen, pembelajaran, dan praktik penyesuaian secara berkelanjutan terkait dengan realitas internal maupun eksternal organisasi yang senantiasa berkembang. Alternatif inovasi model bisnis yang diberikan dapat dijadikan sebagai bahan pertimbangan bagi pasar komunitas yang telah berlangsung saat ini maupun sebagai acuan bagi para inisiator yang akan memulai pasar komunitas makanan sehat. Saran bagi peneliti selanjutnya adalah dapat melakukan penelitian mengenai inovasi model bisnis pada pemangku kepentingan lainnya dalam rantai pasok pangan yang berkelanjutan.

\section{DAFTAR PUSTAKA}

Ati, L., Baga, L. M., \& Satria, A. (2019). Business Model Canvas Non Government Organization (Case Study: Rimbawan Muda Indonesia). Indonesian Journal of Business and Entrepreneurship (IJBE), 5(1).

Bash, K., \& Donnelly, A. (2019). Sustainable Food Systems for a Healthier UK: A discussion paper.

Breuer, H., Fichter, K., Lüdeke-Freund, F., \& Tiemann, I. (2018). Sustainabilityoriented Business Model Development: Principles, Criteria, and Tools. International Journal of Entrepreneurial Venturing, 10(2), 256-286.

Calgary. (2012). Definition of a Sustainable Food System. Diakses pada July 14, 2019, dari https://www.calgary.ca/CA/cmo/Page 
s/Definition-of-a-Sustainable-Food-

System.aspx

Casadesus-Masanell, R., \& Ricart, J. E. (2010). From Strategy to Business Models and onto Tactics. Long Range Planning, 43(2-3), 195215. doi:10.1016/j.lrp.2010.01.004

Cassell, C., Cunliffe, A. L., \& Grandy, G. (2018). The SAGE Handbook of Qualitative Business and Management Research Methods. Los Angeles: SAGE Publications.

Downs, M. Ethan. (2017). The Local Food Movement: A More Sustainable Business Model. Retrieved June 11, 2019, from https://libres.uncg.edu/ir/asu/f/Downs , E_2017 Thesis.pdf.

Feldmann, C., \& Hamm, U. (2015). Consumers' Perceptions and Preferences for Local Food: A Review. Food Quality and Preference, 40 , 152 164.doi:10.1016/j.foodqual.2014.09.0 14

Geissdoerfer, M., Savaget, P., \& Evans, S. (2017). The Cambridge Business Model Innovation process. Procedia Manufacturing, 8, 262-269

Girotra, K., \& Netessine, S. (2013). OM Forum-Business Model innovation for Sustainability. Manufacturing \& Service Operations Management, 15(4), 537-544.

Grove. (2011). SPOT Matrix Leaders' Guide. San Fransisco: The Grove Consultants International. ISBN 1879502-30-5.

Gruchmann, T., Böhm, M., Krumme, K., Funcke, S., Hauser, S., \& Melkonyan, A. (2019). Local and Sustainable Food Businesses: Assessing the Role of Supply Chain Coordination. Innovative Logistics Services and Sustainable Lifestyles, 143163. doi:10.1007/978-3-319-984674_7

Halweil, B. (2004) Eat Here: Reclaiming Homegrown Pleasures in a Global Supermarket, 237 pp. London: W. W.
Norton \& Company Ltd. ISBN 0-39332664-0.

Johnson, M., Christensen, C., Kagermann, H., (2008). Reinventing Your Business Model. Harvard Business Review. 86 (12), 50e59.

Jones, A. (2001). Eating oil. Food Supply in a Changing Climate, 89 pp. Berkshire, UK: Sustain and Elm Farm Research Centre.

Joyce, A., \& Paquin, R. L. (2016). The Triple Layered Business Model Canvas: A Tool to Design More Sustainable Business Models. Journal of Cleaner Production, 135, 14741486.doi:10.1016/j.jclepro.2016.06.0 67

Osterwalder, A., \& Pigneur, Y. (2010). Business Model Generation: A Handbook for Visionaries, Game Changers, and Challengers. New Jersey: Alexander Osterwalder \& Yves Pigneur.

Wibowo, A. S. (16 Mei 2019). Wawancara personal.

Prasetyo, S. D. (1 Juli 2019). Wawancara personal.

Pretty, J. N., Ball, A. S., Lang, T. \& Morison, J. I. L. (2005). Farmcosts and Food Miles: an Assessment of the Full Cost of the UK Weekly Food Basket. Food Policy 30, 1-20. (doi:10.1016/j.foodpol.2005.02.001).

Pucihar, A., Lenart, G., Kljajić Borštnar, M., Vidmar, D., \& Marolt, M. (2019). Drivers and Outcomes of Business Model Innovation-Micro, Small and Medium-Sized Enterprises Perspective. Sustainability, 11(2), 344.

Rahardjo, M. (2017). Studi Kasus dalam Penelitian Kualitatif: Konsep dan Prosedurnya.

Rahdari, A., Sepasi, S., \& Moradi, M. (2016). Achieving Sustainability through Schumpeterian Social Entrepreneurship: The role of Social Enterprises. Journal of Cleaner Production, 137, 347-360. 
Safitri, A. (17 Mei 2019). Wawancara Personal.

Smith, B. G. (2008). Developing Sustainable Food Supply Chains. Philosophical Transactions of the Royal Society B: Biological Sciences, 363(1492), 849861.doi:10.1098/rstb.2007.2187

Stella, D. (2019). Optimized food supply chains to reduce food losses. Saving Food, 227-248. doi:10.1016/b978-012-815357-4.00008-0

Sustain. (2002). Sustainable food chains. Briefing paper 2. Public Sector Catering; Opportunities and Issues Relating Tosustainable Food Procurement, 9 pp. London, UK: Sustain.

Sustainable Food Laboratory. (2005). The purpose of the Sustainable Food Lab is to accelerate the movement ofsustainably produced food from niche to mainstream. Diakses pada: 7 Juli 2019, dari http://www.glifood.org/.

Teece, D. J. (2010). Business Models, Business Strategy and Innovation. Long Range Planning, 43(2-3), 172194.doi:10.1016/j.lrp.2009.07.003

The Economist. (2018). Global Food Security Index 2018: Building Resilience in the face of rising foodSecurity Risks. Diakses pada Juli 2, 2019, dari https://foodsecurityindex.eiu.com/

Van Huy, L., Chi, M. T. T., Lobo, A., Nguyen, N., \& Long, P. H. (2019). Effective Segmentation of Organic Food Consumers in Vietnam Using food-related lifestyles. Sustainability, 11(5), 1237.

Walle, A. H. (2015). Qualitative Research in Business: A Practical Overview. Newcastle Upon Tyne: Cambridge Scholars Publishing. 